\title{
НАСТАВНИК-ФАСИЛИТАТОР ПРОСОЦИЈАЛНОСТИ
}

\author{
Бисера С. Јевтић ${ }^{1}$, Александар Д. Васић
}

Сажетак: Без обзира што су понашања која називамо просоцијалним значајна за остваривање компетентности појединца у скоро свим сферама живота, оно је још увек занемарено поље проучавања и истраживања. Међутим, с обзиром на знатну распрострањеност агресивног и других негативних облика понашања све је већа потреба ка противтежи у чијој основи ће се налазити позитивни облици понашања као што су помагање, дељење, солидарност, разумевање. Највећи утицај на развој просоцијалног понашања ученика и моралну димензију компетентности у школи има, свакако, наставник. Управо због тога предмет овог истраживања је улога наставника у подстицању развоја моралне димензије компетентности личности младих. Резултати нашег истраживања наметнули су педагошку импликацију: измена циљева и задатака васпитања и образовања у смислу већег вођења рачуна о појединцу и развијању оних вредности које доприносе побољшању међуљудских односа и квалитета живота ученика.

Кључне речи: моралност, одговорно понашање, компетентност, просоцијалност.

\section{ТЕОРИЈСКА ОРИЈЕНТАЦИЈА}

С обзиром на чињеницу да живот у једном транзиционом друштву као што је наше са собом носи низ двосмислености, противуречности и неизвесности, оно може бити отежавајући фактор у

\footnotetext{
${ }^{1}$ bisera.jevtic@filfak.ni.ac.rs, Филозофски факултет у Нишу

${ }^{2}$ vasic@vaspks.edu.rs, Висока школа струковних студија за васпитаче Крушевац
} 
усвајању норми, понашања и вредности које се сматрају друштвено пожељним. Јер, управо у контексту двосмислености, неизвесности и противуречности млади често скрену са пута правилног развоја и под утицајем лажне моћи и других спољашњих фактора почињу да усвајају девијантне обрасце понашања. У том смислу улога школе као васпитно-образовне институције јесте да им пружи пуну подршку на путу ка сазревању и помогне у развоју и подстицању оних понашања који су противтежа агресивним и девијантним, а то су просоцијална понашања која су императив савременог демократског друштва.

Под појмом успешног васпитања, пољски педагог Мушињски подразумева спретно и зналачко остваривање васпитних задатака, уочавање васпитних могућности и предузимање одговарајућих иницијатива, подстизање жељених резултата високог степена у васпитним ативностима. Основна својства успешних васпитача односе се на следеће групе: идејно ангажоваље, етичко-васпитну основу, однос према ученицима, тактичност васпитача и однос према задацима у области васпитања. Мушињски изводи седам одредница улоге наставника у савременој школи:

- самостално одређивање операционалних циљева и задатака неопходних активности и њихово прилагођавање могућностима ученика и реалностима васпитнообразовног рада (планирање)

- промишљени избор васпитнообразовних облика и њихово успешно коришћење (организација)

- спретно руковођење и управљање свим елементима одговарајућих образовних ситуација (руковођење)

- стимулисање активности ученика, посебно оних који подстичу самообразовање и самоваспитање (психолошко контактирање)

- стицање угледа, општепожељне позиције и личног ауторитета у очима ученика

- смишљено руковођење разредним колективом у циљу утицања на ученике посредством других ученика (руковођење разредом, групом)

- интегрисање васпитнообразовног процеса, реализованог на различитим етапама од стране разних наставника (обједињавање, интегрисање).

Заједничка ознака ових одредница је њихов инструментални карактер. Добрим наставником се сматра онај који помаже и омогућава великом броју ученика да постигну значајне резултате у раду и учењу, при чему треба успех ограничити на просечно пожељна достигнућа у наставним предметима и значајним подручјима васпитнообразовног и наставног рада (Ђорђевић, 2002: 32)

Диркем истиче да је морални ауторитет главно својство наставника. Наставник треба да верује у свој рад, да је свестан његовог 
значаја, значаја мисије коју обавља. Ауторитет наставника не може долазити споља, већ из њега самога; ом му може доћи само из унутрашње вере. Васпитач треба да верује, не само у себе, не у више вредности своје интелигенције или свог срца, већ у свој задатак и величину свога задатка. Он је огањ једног великог моралног тела које је изнад њега: друштва (Ивковић, 2005: 254).Својстава наставника као што су топлина и разумевање с једне, и имагинативности и подстицајности, с друге стране, су изузетно значајна за најмлађе ученике који у наставницима виде замену за родитеље, као избор прихватања и одобравања. Карактеристично је за ове наставнике да дају много више похвала, награда и охрабрења од других наставника, а понашање ученика настоје увек да тумаче на најбољи могући начин. Због таквих свостава, ови наставници су релативно неауторитативни и веома осетљиви на осећања ученика и њихове афективне одговоре (Ђорђевић, 2002: 38).

Подстицање просоцијалног развоја ученика требало би да буде једна од важних подручја васпитног деловања школе и наставника. Просоцијалном развоју младих доприносе наставници који су усвојили алтруистичке вредности, показују разумевање за ученике и подстичу их на међусобну сарадњу, солидарност и толеранцију. Наставник који се понаша просоцијално ученицима пружа пример, односно модел за угледање, али да би ученици усвојили такво понашање потребно је да однос између наставника и ученика буде заснован на узајамном поверењу и уважавању (Јоксимовић, Гашић-Павишић, 2007: 179).

Стратегије које наставник може користити за подстицање просоцијалног понашања објашњавају Данијелс и Стафорд (Daniels i Stafford) користећи се примерима из свакодневног живота:

- Коришћење спонтаних прилика и означавање просоцијаних поступака деце који се у њима јављају. Када деца помажу у неговању љубимца, треба им објаснити колико су значајни њихови поступци за добробит те животиње.

- У ситуацијама када деца чекају на свој ред и дају другој деци прилику да она дођу на ред, треба им указати да је то начин на који она треба да сарађују.

- Указати на облике просоцијалног понашања, али не моралисати и држати лекције о њима.

- Деци треба пружити прилику да сарађују, а наставник треба јасно да именује и опише поступке сарадње који се појаве. Децу треба подстицати да сама смишљају различите групне пројекте у којима ће сарађивати. 
- Стварати прилике у којима ће деца помагати једна другој. У ситуацијама када је једно дете научило нешто пре осталих, оно може да помаже деци којој је потребна помоћ у тим радњама.

- Указати на конструктивне начине за реаговање на просоцијалне поступке других.

- Сам наставник треба да показује разне просоцијалне поступке, дељење, помагање, сарадњу (према: Јевтић, Кнежевић-Флорић, 2011: 78).

Развијање социјалних вештина усмерено је на подстицање просоцијалног понашања, што је у складу с поставком да одбаченој деци недостају одговарајуће социјалне вештине потребне за успостављање и одржавање позитивних социјалних односа, те да ће, уколико их савладају, моћи да побољшају вршњачке односе и постану социјално прилагођенији. Тако су, на пример, у оквиру различитих програма ученици били обучавани следећим социјалним вештинама: постављање питања, вођство у групи вршњака и пружање вербалне подршке; партиципација, сарадња, комуникација и подршка; давање и примање комплимената, упућивање и прихватање притужби, одбијање неприхватљивих захтева других особа, изражавање емпатије, тражење објашњења, заштита нечијих права, иницирање и одржавање конверзације. Пошто социјално компетентно понашање захтева и одговарајуће социокогнитивне вештине (интерпретирање социјалне ситуације на конструктиван начин, познавање друштвено прихватљивих социјалних циљева и стратегија, давање социјално адекватних решења за различите социјалне ситуације), то је у неким програмима заснованим на моделу социокогнитивног учења где је акценат стављен на подучавање ефикасним социокогнитивним стратегијама, примени социјалног знања и евалуацији понашања у одређеном социјалном контексту. Поменуте вештине обухватају решавање социјалних проблема, самоконтролу, прихватање последица свог понашања, избегавање невоља. Основни циљеви већине програма намењених развијању социјалних вештина и/или редукцији проблема у понашању су: стицање социјалних вештина; испољавање тих вештина; смањење или елиминисање проблема у понашању и генерализација социјалних вештина (Спасеновић, Мирков, 2007).

За унапређивање социјалних вештина ученика у оквиру програма усмерених на побољшање интерперсоналне компетентности користе се различите технике, а најчешће: подучавање, моделовање, увежбавање понашања и позитивно поткрепљење.

Подучавање подразумева директну вербалну обуку усмерену на разумевање појединих социјалних вештина, односно облика понашања значајних за социјалну интеракцију. Рецимо, појмови које ученик треба 
да усвоји су: партиципација, комуникација, сарадња, подршка. Дискутовање о значењу и значају одговарајућих социјалних вештина праћено је давањем конкретних примера таквог понашања, што омогућава ученику да разуме зашто, у којим ситуацијама и који је смисао испољавања просоцијалног понашања. Тако, примери понашања значајних за комуникацију су: разговор с другима, слушање док други говоре, постављање питања о активности у којој се учествује или о другим особама, изношење мишљења о активности или о самом себи, посматрање понашања друге особе итд. Сматра се да примена само подучавања не утиче значајно на испољавање просоцијалног понашања, али да у комбинацији с другим бихевиоралним техникама даје задовољавајуће резултате (Спасеновић, Мирков, 2007).

Повећање нивоа или фреквенције јављања различитих социјално пожељних понашања захтева и позитивно поткрепљење. Награду или повољне исходе за појединца може чинити социјално одобравање или подршка, специјалне привилегије или активности. Без обзира на то која се врста поткрепљења или подстицања користи, важно је да похвала уследи што пре након појављивања жељене реакције, посебно уколико се развија нова вештина код детета, као и да се често примењује. У сваком случају, много веће шансе за успех у развијању социјалних вештина деце постоје уколико су интервентни програми засновани на примени више различитих техника, а не на једној одређеној.

\section{МЕТОДОЛОШКА ОРИЈЕНТАЦИЈА}

\section{Предмет истражсивања}

Просоцијално понашање и социјално одговорно понашање чини суштинску карактеристику људских односа, узајамних веза са другим особама. Заправо, понашање усмерено ка добробити другог, представља једну од основних вредности на којима се заснивају међуљудски односи, а могло би се рећи и квалитет живота човека. Оно је значајно за остваривање компетентности појединца у различитим сферама живота: академској, социјалној, породичној, професионалној. Управо збод тога важно је подстицати просоцијално понашање и моралност младих. Школа представља један од чинилаца који могу допринети развоју просоцијалног понашања. Највећи утицај на развој просоцијалног понашања ученика и моралну димензију компетентности у школи има свакако наставник. Управо због тога предмет овог истраживања је улога наставника као фасилитатора у подстицању развоја моралне димензије компетентности личности младих која обухвата просоцијалност. 
На основу овако конципираног проблема истраживања може се уочити његова комплексност, а пре свега педагошки и шири друштвени значај. Педагошки значај огледа се у систематизовању и увећавању научних сазнања о подстицању социјално одговорног понашања код младих, па сходно томе у могућностима примене тих сазнања на унапређивање васпитно-образовне праксе. Узимајући у обзир наведено, ово истраживање с обзиром на проблем који истражује даје допринос развоју педагошке теорије и праксе. У ширем, друштвеном контексту проблем подстицања просоцијалности младих посматра се не само као део педагошких него и осталих наука хуманистичке орјентације (филозофских, психолошких, социолошких, културолошких и сл.).

\section{Циљ истраживана}

Циљ овог истраживања јесте утврђивање успешности наставника кроз улогу фасилитатора у подстицању развоја моралне димензије просоцијалне компетентности личности младих.

\section{Задаџи истраживања}

1. Испитати начин подстицања просоцијалног понашања ученика од стране наставника као фасилитатора.

2. Испитати којим активностима и васпитним стиловима наставници подстичу просоцијално понашање ученика и моралну димензију компетентности.

3. Утврдити садржај програма за развијање социјалних вештина којим наставници подстичу просоцијалност.

\section{Методе, технике, инструменти}

Метода примењена у овом истраживању одабрана је у складу са природом проблема, предметом, циљем и задацима истраживања као и у складу са постављеним хипотезама. За потребе овог истраживања користиле су се дескриптивна и каузална (неекспериментална) метода приликом обраде и интерпретације података. С обзиром на комплексност и мултидимензионалност феномена социјално одговорно просоцијално понашање који ће се истражити, било је неопходно добијене податке упоредити, утврдити њихову повезаност и тумачити. 
Као инструмент истраживања коришћена је скала Ликертовог типа за наставнике и то: Упитник ставова и понашања наставника фасилитатора о одговорном просоцијалном понашању ученика SOPPU.

\section{Узорак}

Истраживање је спроведено на пригодном узорку субјеката од 168 наставника разредне наставе у пет основних школа у Крушевцу.

\section{Начини и нивои статистичке обраде података}

У складу са проучаваним проблемом и коришћеним истраживачким методама, примењени су одговарајући статистички поступци који омогућавају приказивање добијених података и њихову анализу. У обради података коришћен је специјализовани софтвер за статистичку обраду података (SPSS for Windows 17.0). Од метода анализе података коришћена је: а) дескриптивна статистика (фреквенце и проценти); б) корелативне технике ради утврђивања повезаности међу варијаблама; в) анализа варијансе (ANOVA) ради утврђивања разлике међу варијаблама; и г) поузданост инструмената (Krombah Alpha);

Овим истраживањем обухваћен је један од комплекснијих проблема са којим се сусрећемо у данашње време.

\section{ДИСКУСИЈА}

Један од начина подстицања просоцијалног понашања је учење путем вербалне прескрипције. Уколико наставници својим ученицима говоре о толеранцији, значају сарадње, емпатији, разумевању других и сл. велике су шансе да ће таква осећања пробудити и код својих ученика.

У основи сваког од облика социјално одговорног просоцијалног понашања налази се одређена морална вредност. Да би ученици усвојили и испољили неки од облика просоцијалног понашања, потребно је најпре да усвоје вредности које леже у њиховој основи. Постоји велики број начина којима је могућ начин усвајања ових вредности, а од креативности наставника зависи како ће подстицати ученике да усвоје вредности релевантне за одређену врсту просоцијалног понашања. Анализирањем података добили смо да $68.18 \%$ наставника кроз разговор са ученицима о вредностима као што 
су поштење, племенитост, алтруизам, одговорност подстиче ученике да усвоје вредности релевантне за одређену врсту просоцијалног понашања, 20.45\% наставника разговор о датим вредностима поткрепљује адекватним примерима из литературе, $4.55 \%$ наставника користи филмске материјале како би приказао-ла примере просоцијалног понашања и тиме подстакли ученике на усвајање вредности, док се $6.82 \%$ наставника не бави овом тематиком.

Облици и методе рада могу допринети развоју социјално одговорног просоцијалног понашања. Кооперативно учење, као скуп наставних метода којима се ученици подстичу да раде заједно у малим групама, поред доприноса школском успеху, има ефекте и на просоцијално понашање ученика. Учење у малим групама доводи до бољих интерперсоналних односа међу ученицима, развија се способност преузимања улоге другога, смањује се број конфликата и подстиче просоцијално понашање. Да би остварили заједнички циљ, ученици у кооперативним групама помажу једни другима и узајамно се охрабрују. Такође кооперативно учење у школи подстиче позитивне ставове према различитости и доприносе бољим односима међу ученицима који се међусобно разликују у погледу пола, социјалног порекла, способности, етничке припадности. На тај начин се смањују предрасуде и социјална дистанца између припадника појединих група, као извор сукоба и препрека просоцијалном понашању.

Наставник може својим вештинама, понашањем и начином рада умногоме да допринесе успостављању повољне социјалне климе у разреду, школском постигнућу својих ученика, као и развоју моралне просоцијалне оријентације. Да би до таквих ефеката дошло, потребно је да наставник буде свестан важности остваривања позитивних интеракција у разреду и постојања добрих интерперсоналних односа, као и сопствене улоге у креирању подстицајне атмосфере. Да би допринели алтруизму ученика, наставници према ученицима треба да се опходе срдачно, да показују заинтересованост за ученике и њихове потребе, али и да од ученика захтевају одговорност. Развоју просоцијалног понашања погодује демократски начин руковођења разредом када наставник подстиче ученике на активност и сарадњу, охрабрује их да постављају питања и изложе своја мишљења, толерише различите идеје и ставове. Подаци добијени овим истраживањем у складу су са овим теоријским чињеницама, али и са претпоставком да наставници демократским васпитним стилом подстичу социјално одговорно просоцијално понашање ученика.

Истраживања просоцијалног понашања у оквиру којих су укључени алтруизам и слични појмови који доприносе укупном просоцијалном понашању указују да се „проучавање алтруизма може 
сагледавати као облик социјалног понашања у склопу процеса социјализације, као атрибут личности и као део људске природе“ Ако сагледамо резултате које смо добили у нашем истраживању, у оквиру којег су биле укључене различите форме просоцијалног понашања као што је ученичка емпатија, социјализовано реаговање, активно помагање, осетљивост за друге, отвореност за друге и сарадљивост са наставницима, можемо закључити да су подаци у складу са наведеном дефиницијом у вези емпатијског односа према другима и то у два домена: први, који казује да је емпатија (просоцијално понашање) део социјализације и други који казује да је емпатија део особина личности, што је такође у складу са резултатима нашег истраживања јер доминантно не постоји повезаност мерених субскала просоцијалног понашања код ученика са субскалама којима се утврђује наставнички рад на подстицању просоцијалног понашања.

Од личности наставника, од тога колико је и он сам просоцијално оријентисан, од његове креативности и других особина зависи, у којој мери ће наставник подстицати развој моралне димензије компетентности личности младих.

Различитим скалама можемо одредити који су облици просоцијалног понашања и у којој мери су изражени код ученика, као и ефекат фасилитаторске улоге наставника. Податке које добијемо, можемо упоредити са начинима, васпитним средствима, облицима рада, васпитним стиловима и свим другим активностима којима наставници настоје да подстакну социјално одговорни просоцијални развој младих, како би смо увидели колики је ефекат утицаја наставника на развој моралне деимезије компетентне личности младих. Испитивањем овог проблема, у неком од следећих истраживања, област одговорног просоцијалног понашања, добиће на још већем значају.

Резултати нашег истраживања наметнули су педагошку импликацију: измена циљева и задатака васпитања и образовања у смислу већег вођења рачуна о појединцу и развијању оних вредности које доприносе побољшању међуљудских односа и квалитета живота ученика.

\section{ЗАКљУЧАК}

Просоцијално понашање, тј. позитивно социјално понашање представља есенцијалну карактеристику људских односа, узајамних веза са другим особама. Представља једну од основних вредности на којима се заснивају међуљудски односи али и квалитет живота човека. Оно је значајно за остваривање компетентности појединца у различитим сферама живота: академској, социјалној, породичној, 
професионалној. Чињеница је да свако развијено друштво тежи развоју алтруистичког понашања, макар и у облику спремности за помагање припадницима властите етничке групе или и чланове других група. Најчешће се као основно средство у развоју оваквог понашања користи вербално убеђивање које зарад ефективности мора бити праћено одговарајућим поступцима, поткрепљивање као нешто ефикаснији начин његовог развоја. При том не треба превидети различите облике социјалног учења (поткрепљивање, учење по моделу, давање примера) као и различите агенсе социјализације где се нарочит значај придаје родитељима. Развијање алтруистичких моралних норми и одређене особине личности јесу пратиоци и покретачи алтруистишког понашања и то: осетљивост за туђе потребе и одговорност за властите поступке пред самим собом, а све то у циљу интернализације алтруистичког понашања и његовог задржавања као трајног. С озиром да је просоцијално понашање у бити понашање које доприноси добробити другога и обухвата широк опсег различитих облика понашања као што је давање материјалних добара, пружање психо-социјалне подршке и помоћи, спремност на сарадњу, показивање љубазности, помагање у обављању неког посла може се увидети да је реч о једном комплексном, мултидимензионалном феномену који се испољава кроз више димензија о којима сведоће и бројна истраживања. Иста такође указују на велику врсту индикатора једног оваквог понашања који се међусобно разликују у погледу потребних компетенција, садржаја, трајања, улагања и ризика. Притом, не треба изгубити из вида да се просоцијални поступци разликују и по томе да ли се до њих долази самоиницијативно или на нечији захтев, да ли су спонтани или интенционални као и да ли се починилац доброг дела и прималац међусобно познају и у каквом су односу. Хетерогеност и међусобна неуједначеност ових индикатора просоцијалног понашања јесте најчешћи узрок немогућности поређења резултата, уопштавања па и погрешних закључака.

Кооперативне стратегије теже да промене социјалну средину и квалитет социјалних односа у одељењу. Кооперативне стратегије варирају два главна аспекта разредне организације наставника као фасилитатора, и то: структуру задатка и структуру награђивања ученика. Задаци морају бити реструктуисани тако да би се створила међузависност, помагање и сарадња. Дискусија о моралним проблемима удружена са искуствима учења путем сарадње подстиче развој дечије осетљивости за многе аспекте морланог мишљења. Један од основних механизама који се налазе у основу просоцијалног понашања јесте способност децентрације. 
За разлику од компетитивне социјалне ситуације у којој се успех тј. награда једног ученика јавља на рачун неуспеха другог ученика, у кооперативној ситуацији коју карактерише позитивна међузависност награђивања, успех и награда јесу резултат заједничког делованаја свих припадника групе. С обзиром на то да се награде (похвале, признања) дају групи и засноване су на групном постигнућу, јавља се ситуација у којој успех једног ученика помаже другом да буде успешан. Дакле, реструктуисање основних димензија живота у разреду, укључујући моделе комуникације вршњака и комуникације између наставника и ученика ствара социјалну ситуацију која је неопходна да би се подстакле и интернализовале просоцијалне вештине. Просоцијално понашане се може развијати само ако је интегрални део процеса учења.

\section{ЛИТЕРАТУРА:}

Ђорђевић, Ј. (2002). Својства наставника и проиењивање ғиховог рада. Вршац: Виша школа за образовање васпитача.

Ивковић, М. (2005). Сочиологија образовања (друго допуњено издање). Врање: Учитељски факултет.

Јоксимовић, С., Гашић-Павишић, С. (2007). Подстицање просоиијалне оријентаиије младих у породищи и школи. Београд: Институт за педагошка истраживања.

Јевтић, Б., Кнежевић-Флорић, О. (2011). Изазови соиијалнопедагошке делатности. Ниш: Филозофски факултет.

Спасеновић, В. (2004). Просоиијално понашање и школско постигнуће ученика. Београд: Институт за педагошка истраживања, 131-150.

Спасеновић, В., Мирков, С. (2007.) „Интервентни програми за развој социјалних вештина“. Настава и васпитање, Београд, број 1.

Шевкушић, С., Милошевић, Н. (2004). Да ли успешан наставник васпитава као добар родитељ. Београд: Институт за педагошка истраживања, 188-203. 
Abstract: Even though behaviours we call prosocial are significant for achieving individual competency in almost all spheres of life, they are still a neglected area of investigation and study. However, in light of considerable spread of aggressive and other negative behaviours, there is a pronounced need for countermeasures in the form of positive behaviours such as helping, sharing, solidarity and understanding. The most important factor in the development of prosocial behaviour in students and moral dimension of competency in schools are certainly teachers. This is the reason why this paper deals with the role of teachers in the development of moral dimension of competency in personality of young people. The findings of the investigation raise the following pedagogic implication: the objectives and outcomes of education and upbringing should be adapted so that greater emphasis should be placed on individuals as well as on the development of values leading to better human relations and students' quality of life.

Key terms: Morality, responsible behaviour, competency, prosociality

Примљен. 29. августа 2014.

Прихваћен. 21. октобра 2014. 